\title{
Assessment of Undiscovered Oil and Gas Resources in the Cretaceous Nanushuk and Torok Formations, Alaska North Slope, and Summary of Resource Potential of the National Petroleum Reserve in Alaska, 2017
}

The U.S. Geological Survey estimated mean undiscovered, technically recoverable resources of 8.7 billion barrels of oil and 25 trillion cubic feet of natural gas (associated and nonassociated) in conventional accumulations in the Cretaceous Nanushuk and Torok Formations in the National Petroleum Reserve in Alaska, adjacent State and Native lands, and State waters. The estimated undiscovered oil resources in the Nanushuk and Torok Formations are significantly higher than previous estimates, owing primarily to recent, larger than anticipated oil discoveries.

\section{Introduction}

Recent exploration drilling has resulted in significant oil discoveries in the Cretaceous Nanushuk and Torok Formations in and near the National Petroleum Reserve in Alaska (NPR-A). These new discoveries have spurred exploration activity in the region and have increased demand for enhanced information regarding the oil-resource potential of these formations.

New U.S. Geological Survey (USGS) estimates of undiscovered, technically recoverable oil and gas resources in conventional accumulations across the entire onshore and State-waters extent of the Nanushuk and Torok Formations update previous assessments for these two formations (Bird and others, 2005; Houseknecht and others, 2010). This fact sheet also includes a summary of 2010 assessment results for older rocks in the NPR-A; no updated assessment was conducted as those rocks have not been penetrated by exploration drilling since 2010 , and thus no new information is available about their oil and gas potential.

\section{Recent Oil Discoveries}

Prior to 2015, about 150 exploration wells had penetrated the Nanushuk and Torok Formations, yet oil production had been established in just one small oil pool (less than 10 million barrels of recoverable oil [MMBO]) in each formation. The potential for undiscovered oil accumulations in both formations was recognized in previous USGS assessments, but the size of undiscovered pools was considered to be modest based on historical exploration results (Houseknecht, 2003).

Multiple oil discoveries announced during 2015-2017 indicate that the potential for large oil accumulations in both formations is greater than previously thought. Discovery of the Pikka oil pool in the Nanushuk Formation was announced

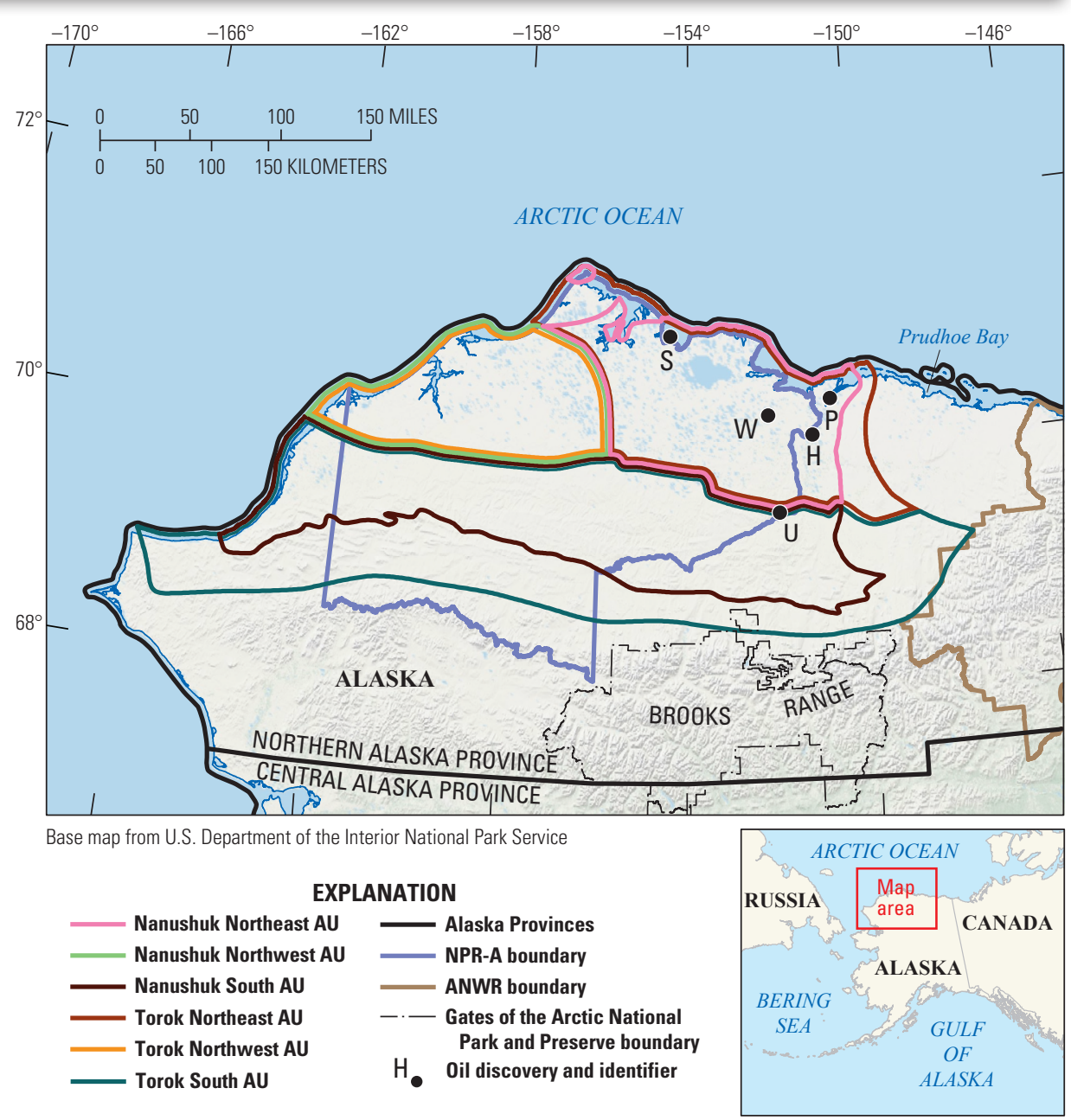

Figure 1. Map of Northern Alaska showing boundaries of the six assessment units (AUs) in the National Petroleum Reserve in Alaska (NPR-A) and adjacent areas. Assessment units include State waters. Older AUs assessed in 2010 are not shown. (ANWR, Arctic National Wildlife Refuge; H, Horseshoe; P, Pikka; S, Smith Bay; U, Umiat; W, Willow)

in 2015 and followed by the 2017 apparent confirmation of an extension of the same oil pool at Horseshoe, 21 miles south of the Pikka discovery (fig. 1). Industry estimates suggest that the Pikka-Horseshoe pool may hold more than 1,000 MMBO. Discovery of the Willow oil pool (fig. 1) in the Nanushuk Formation was announced in 2017, with estimated resources of more than $300 \mathrm{MMBO}$. 
A significant oil discovery in the deeper Torok Formation was announced in 2016 at Smith Bay, less than 1 mile offshore from the NPR-A (fig. 1). The industry announcement of the discovery suggests that the Smith Bay oil pool may contain more than 1,000 MMBO.

The ultimate volume of oil that may be produced from each of these discoveries will remain uncertain until development drilling and oil production are initiated. Nevertheless, a sufficient amount of data is available to confirm that the potential size of oil pools in the Nanushuk and Torok Formations is larger than previously thought. Moreover, availability to the USGS assessment team of three-dimensional (3D) seismic reflection data in the northeastern NPR-A and adjacent State lands and waters provided a capability to estimate the number and size of seismic amplitude anomalies, which are considered viable proxies for undrilled prospects.

\section{Geological Framework and Definition of Assessment Units}

The Nanushuk and Torok Formations together form a huge wedge of sediment deposited in a deep water basin and are preserved north of the Brooks Range beneath the Alaska North Slope and adjacent offshore. The Torok Formation was deposited on the floor of the deep basin and on a shallowing-upward slope and includes potential reservoirs in turbidite sandstones. The Nanushuk Formation was deposited in shallow water and includes potential reservoirs in deltaic, shoreface, and fluvial sandstones. The largescale geometry of these sedimentary deposits is preserved in the rock formations and imaged by seismic reflection data (fig. 2).

The new discoveries in both formations involve oil pools in stratigraphic traps concentrated along ancient shelf margins. Stratigraphic traps display subtle geometries that are challenging to recognize using seismic-reflection data. However, application of innovative 3D seismic techniques improves exploration success rates, as indicated by the recent Nanushuk and Torok discoveries.

The USGS used vintage two-dimensional (2D) and recent 3D seismic data, where available, and data from exploration wells and outcrops to map the distribution and internal geometry of the Nanushuk and Torok Formations. This research resulted in the definition of three assessment units (AUs) in each formation (fig. 1). The Nanushuk Northeast and Torok Northeast AUs are defined by the geometry of a distinctive boundary between the two formations (shelf-margin trajectory) (Houseknecht and others, 2009) that suggests favorable conditions for stratigraphic traps to have formed during deposition. In contrast, the geometry of the shelf-margin trajectory is considered less favorable for the development of stratigraphic traps in the western part of the study area, resulting in the Nanushuk Northwest and Torok Northwest AUs (fig. 1). The Nanushuk South and Torok South AUs are defined by the presence of large-scale folds and faults and by evidence that the rocks have been heated to temperatures at which oil is converted to natural gas. These geological contrasts between the two

formations and among the northeast, northwest, and south areas were used to define key assessment input data (table 1).

The four northern AUs are inferred to contain mainly stratigraphic traps, with fewer combination stratigraphic-structural traps. The two northeastern AUs are inferred to contain mainly oil-charged traps with fewer gas-charged traps, mainly near the southern boundary. The two northwestern AUs are inferred to contain oil-charged traps and a larger proportion of gas-charged traps because of source-rock character and evidence for a northward gas flush during Late Cretaceous and early Cenozoic uplift in the northwestern NPR-A (Houseknecht and others, 2010).

The two southern AUs are inferred to contain mainly structural traps, with fewer combination structural-stratigraphic traps. These two AUs are considered to contain mainly gas-charged traps because of elevated thermal maturity, with a small number of oil-charged traps. The potential for oil-charged structural traps is demonstrated by the Umiat oil pool (fig. 1), discovered in an anticlinal trap in 1946 and estimated to hold more than $70 \mathrm{MMBO}$ (never produced).

Sandstone reservoirs in both the Nanushuk and Torok Formations are mainly fine grained and prone to reduction of porosity and permeability with burial. Deeper parts of the assessment units, therefore, may have reduced reservoir quality that jeopardizes the economic viability of oil accumulations. This issue is more likely to affect Torok reservoirs because they are buried 2,000 4,000 feet deeper than Nanushuk reservoirs in the same area (fig. 2).

\section{Undiscovered Resources Summary}

Assessed mean resources for the six AUs in the Nanushuk and Torok Formations are 8,727 MMBO, or 8.7 billion barrels of oil, and 24,545 billion cubic feet of recoverable gas (BCFG), or 25 trillion cubic feet of recoverable gas, which includes 6,992 BCFG of associated gas and 17,553 BCFG of nonassociated gas (table 2). All these estimates are associated with large ranges of uncertainty (table 2, range of results between F95 and F5), a reflection of the immature stage of exploration for 
Table 1. Key input data for six conventional assessment units in the Nanushuk and Torok Formations in the National Petroleum Reserve in Alaska and adjacent areas.

[AU, assessment unit; MMBO, million barrels of recoverable oil; BCFG, billion cubic feet of recoverable gas; $\mathrm{km}^{2}$, square kilometer. Shading indicates not applicable]

\begin{tabular}{|c|c|c|c|c|c|c|c|c|}
\hline \multirow{2}{*}{ Assessment input data } & \multicolumn{4}{|c|}{ Nanushuk Northeast AU } & \multicolumn{4}{|c|}{ Nanushuk Northwest AU } \\
\hline & Minimum & Median & Maximum & Calculated mean & Minimum & Median & Maximum & Calculated mean \\
\hline Number of oil fields & 10 & 60 & 325 & 69.4 & 5 & 35 & 200 & 40.8 \\
\hline Number of gas fields & 1 & 10 & 50 & 11.4 & 3 & 15 & 100 & 18.0 \\
\hline Sizes of oil fields (MMBO) & 5 & 15 & 5,000 & 70.0 & 5 & 8 & 2,500 & 31.3 \\
\hline Sizes of gas fields (BCFG) & 30 & 90 & 30,000 & 420.0 & 30 & 48 & 15,000 & 187.5 \\
\hline AU probability & 1.0 & & & & 0.9 & & & \\
\hline AU area $\left(\mathrm{km}^{2}\right)$ & 29,874 & & & & 23,803 & & & \\
\hline \multirow{2}{*}{ Assessment input data } & \multicolumn{4}{|c|}{ Nanushuk South AU } & \multicolumn{4}{|c|}{ Torok Northeast AU } \\
\hline & Minimum & Median & Maximum & Calculated mean & Minimum & Median & Maximum & Calculated mean \\
\hline Number of oil fields & 1 & 2 & 10 & 2.3 & 4 & 40 & 200 & 45.7 \\
\hline Number of gas fields & 5 & 20 & 100 & 22.8 & 1 & 8 & 40 & 9.1 \\
\hline Sizes of oil fields (MMBO) & 5 & 8 & 2,500 & 31.3 & 5 & 10 & 4,000 & 47.7 \\
\hline Sizes of gas fields (BCFG) & 30 & 48 & 15,000 & 187.5 & 30 & 60 & 24,000 & 286.4 \\
\hline AU probability & 1.0 & & & & 1.0 & & & \\
\hline AU area $\left(\mathrm{km}^{2}\right)$ & 43,861 & & & & 37,354 & & & \\
\hline \multirow{2}{*}{ Assessment input data } & \multicolumn{4}{|c|}{ Torok Northwest AU } & \multicolumn{4}{|c|}{ Torok South AU } \\
\hline & Minimum & Median & Maximum & Calculated mean & Minimum & Median & Maximum & Calculated mean \\
\hline Number of oil fields & 2 & 15 & 75 & 17.1 & 1 & 3 & 15 & 3.4 \\
\hline Number of gas fields & 1 & 5 & 25 & 5.7 & 5 & 20 & 100 & 22.8 \\
\hline Sizes of oil fields (MMBO) & 5 & 7 & 2,500 & 27.4 & 5 & 6 & 1,000 & 14.8 \\
\hline Sizes of gas fields (BCFG) & 30 & 47 & 15,000 & 164.7 & 30 & 36 & 6,000 & 88.5 \\
\hline AU probability & 0.9 & & & & 1.0 & & & \\
\hline AU area $\left(\mathrm{km}^{2}\right)$ & 23,832 & & & & 78,372 & & & \\
\hline
\end{tabular}

stratigraphic traps in these formations. The assessed resources are also not equally distributed, either spatially or by formation.

The largest undiscovered oil resources are assessed in the two northeastern AUs. The Nanushuk Northeast AU is estimated to hold between 1,271 and 11,162 MMBO (F95-F5) with a mean of 4,862 MMBO. The Torok Northeast AU is estimated to hold between 466 and 5,417 MMBO (F95-F5) with a mean of 2,177 MMBO. Assessed oil resources are smaller in the northwest AUs. The Nanushuk Northwest AU is estimated to hold between 0 and 3,152 MMBO (F95-F5) with a mean of 1,146 MMBO. The Torok Northwest AU is estimated to hold between 0 and 1,379 MMBO (F95-F5) with a mean of 421 MMBO. Assessed oil resources are smallest in the southern AUs. The Nanushuk South AU is estimated to hold between 6 and $266 \mathrm{MMBO}$ (F95-F5) with a mean of $71 \mathrm{MMBO}$. The Torok South AU is estimated to hold between 11 and $161 \mathrm{MMBO}$ (F95-F5) with a mean of $50 \mathrm{MMBO}$.

Assessed gas resources are largest in the Nanushuk Northeast AU, with an estimated mean total for associated plus nonassociated gas of 8,689 BCFG. Assessed mean estimates for gas resources are substantially smaller in the other AUs (table 2). All six of the Nanushuk and Torok AUs are assessed to contain natural gas liquids (NGL) associated with both oil and gas accumulations, with the Nanushuk Northeast AU estimated to contain mean resources of 74 million barrels of NGL (table 2).

Table 2 includes a summary of results from the 2010 assessment of rocks older than the Torok Formation in the NPR-A, which were estimated to hold $86 \mathrm{MMBO}$ and 14,732 BCFG (Houseknecht and others, 2010). When those assessed values are added to the new results from the Nanushuk and Torok AUs, the oil estimate ranges from 1,754 to 21,859 MMBO (F95-F5) with a mean of $8,813 \mathrm{MMBO}$, and the total gas (associated plus nonassociated) estimate ranges from 5,507 to 112,932 BCFG (F95-F5) with a mean of 39,277 BCFG (about 39 trillion cubic feet of gas).

\section{Acknowledgments}

The USGS acknowledges the Bureau of Land Management, Alaska Region, and the Bureau of Ocean Energy Management, Alaska Outer Continental Shelf Region, for outstanding collaboration in reviewing 3D seismic and other data and in discussing geological constraints for the Nanushuk and Torok AUs.

\section{References Cited}

Bird, K.J., Houseknecht, D.W., Attanasi, E.D., Moore, T.E., Nelson, P.H., Potter, C.J., Schenk, C.J., Schuenemeyer, J.H., Verma, M.K., Saltus, R.W., Phillips, J.D., Charpentier, R.R., Cook, T.A., Klett, T.R., and Pollastro, R.M., 2005, Oil and gas assessment of central North Slope, Alaska, 2005: U.S. Geological Survey Fact Sheet 2005-3043, 2 p., accessed December 7, 2017, at http://pubs.usgs.gov/fs/2005/3043/fs2005-3043.pdf.

Houseknecht, D.W., 2003, Brookian stratigraphic plays in the National Petroleum Reserve-Alaska (NPRA): U.S. Geological Survey Open-File Report 03-039, 34 p. plus tables and figures, accessed December 7, 2017, at http://pubs.usgs.gov/of/2003/ of03-039/.

Houseknecht, D.W., Bird, K.J., and Schenk, C.J., 2009, Seismic analysis of clinoform depositional sequences and shelf-margin trajectories in Lower Cretaceous (Albian) strata, Alaska North Slope: Basin Research, v. 21, no. 5, p. 644-654.

Houseknecht, D.W., Bird, K.J., Schuenemeyer, J.H., Attanasi, E.D., Garrity, C.P., Schenk, C.J., Charpentier, R.R., Pollastro, R.M., Cook, T.A., and Klett, T.R., 2010, 2010 updated assessment of undiscovered oil and gas resources of the National Petroleum Reserve in Alaska (NPRA): U.S. Geological Survey Fact Sheet 2010-3102, 4 p., accessed December 7, 2017, at https://pubs.usgs.gov/fs/2010/3102/pdf/FS10-3102.pdf. 
Table 2. New assessment results for six conventional assessment units in the Nanushuk and Torok Formations in the National Petroleum Reserve in Alaska and adjacent areas. Results of 2010 assessment for conventional oil and gas resources in older rocks in the NPR-A are also included for completeness (Houseknecht and others, 2010).

[MMBO, million barrels of oil; BCFG, billion cubic feet of gas; NGL, natural gas liquids; MMBNGL, million barrels of natural gas liquids. Results shown are fully risked estimates. For gas accumulations, all liquids are included in the NGL category. F95 represents a 95-percent chance of at least the amount tabulated; other fractiles are defined similarly. Fractiles are additive under the assumption of perfect positive correlation. Shading indicates not applicable]

\begin{tabular}{|c|c|c|c|c|c|c|c|c|c|c|c|c|c|c|}
\hline \multirow{3}{*}{ Assessment units (AUs) } & \multirow{3}{*}{$\begin{array}{c}\text { AU } \\
\text { prob- } \\
\text { ability }\end{array}$} & \multirow{3}{*}{$\begin{array}{l}\text { Accumu- } \\
\text { Iation } \\
\text { type }\end{array}$} & \multicolumn{12}{|c|}{ Total undiscovered resources } \\
\hline & & & \multicolumn{4}{|c|}{ Oil (MMBO) } & \multicolumn{4}{|c|}{ Gas (BCFG) } & \multicolumn{4}{|c|}{ NGL (MMBNGL) } \\
\hline & & & F95 & F50 & F5 & Mean & F95 & $\mathrm{F} 50$ & F5 & Mean & F95 & F50 & F5 & Mean \\
\hline \multicolumn{15}{|c|}{2017 Nanushuk and Torok Assessment Units } \\
\hline \multirow{2}{*}{ Nanushuk Northeast AU } & \multirow{2}{*}{1.0} & Oil & 1,271 & 4,042 & 11,162 & 4,862 & 945 & 3,164 & 9,304 & 3,884 & 9 & 32 & 95 & 39 \\
\hline & & Gas & & & & & 553 & 2,998 & 15,538 & 4,805 & 4 & 22 & 115 & 35 \\
\hline \multirow{2}{*}{ Nanushuk Northwest AU } & \multirow{2}{*}{0.9} & Oil & 0 & 878 & 3,152 & 1,146 & 0 & 688 & 2,574 & 917 & 0 & 7 & 25 & 9 \\
\hline & & Gas & & & & & 0 & 1,940 & 9,923 & 3,029 & 0 & 14 & 74 & 22 \\
\hline \multirow{2}{*}{ Nanushuk South AU } & \multirow{2}{*}{1.0} & Oil & 6 & 26 & 266 & 71 & 5 & 20 & 212 & 57 & 0 & 0 & 2 & 1 \\
\hline & & Gas & & & & & 873 & 3,098 & 11,901 & 4,264 & 6 & 23 & 93 & 33 \\
\hline \multirow{2}{*}{ Torok Northeast AU } & \multirow{2}{*}{1.0} & Oil & 466 & 1,720 & 5,417 & 2,177 & 348 & 1,342 & 4,479 & 1,738 & 5 & 20 & 71 & 27 \\
\hline & & Gas & & & & & 277 & 1,446 & 8,887 & 2,590 & 3 & 15 & 100 & 29 \\
\hline \multirow{2}{*}{ Torok Northwest AU } & \multirow{2}{*}{0.9} & Oil & 0 & 267 & 1,379 & 421 & 0 & 210 & 1,121 & 336 & 0 & 3 & 18 & 5 \\
\hline & & Gas & & & & & 0 & 388 & 3,148 & 845 & 0 & 4 & 35 & 9 \\
\hline \multirow{2}{*}{ Torok South AU } & & Oil & 11 & 27 & 161 & 50 & 10 & 32 & 196 & 60 & 0 & 0 & 2 & 1 \\
\hline & 1.0 & Gas & & & & & 550 & 1,539 & 5,220 & 2,020 & 4 & 12 & 41 & 16 \\
\hline Subtotals & & & 1,754 & 6,960 & 21,537 & 8,727 & 3,561 & 16,865 & 72,503 & 24,545 & 31 & 152 & 671 & 226 \\
\hline & & & 10 Bea & ufortian & and Elles & nerian $\mathrm{A}$ & ssessm & nt Units & & & & & & \\
\hline Beaufortian Cretaceous & & Oil & 0 & 0 & 48 & 8 & 0 & 0 & 36 & 6 & 0 & 0 & 1 & 0 \\
\hline Topset North AU & 0.9 & Gas & & & & & 0 & 592 & 1,685 & 670 & 0 & 6 & 18 & 7 \\
\hline Beaufortian Upper Jurassic & & Oil & 0 & 26 & 80 & 33 & 0 & 28 & 82 & 34 & 0 & 0 & 1 & 0 \\
\hline Topset Northeast AU & 1.0 & Gas & & & & & 829 & 2,415 & 5,254 & 2,638 & 8 & 23 & 50 & 25 \\
\hline Beaufortian Upper Jurassic & 10 & Oil & 0 & 0 & 0 & 0 & 0 & 0 & 0 & 0 & 0 & 0 & 0 & 0 \\
\hline Topset Northwest AU & 1.0 & Gas & & & & & 251 & 967 & 2,211 & 1,047 & 3 & 12 & 27 & 13 \\
\hline Beaufortian Lower Jurassic & & Oil & 0 & 0 & 0 & 0 & 0 & 0 & 0 & 0 & 0 & 0 & 0 & 0 \\
\hline Topset AU & 1.0 & Gas & & & & & 866 & 4,074 & 9,839 & 4,552 & 8 & 39 & 95 & 44 \\
\hline & & Oil & 0 & 0 & 91 & 21 & 0 & 0 & 60 & 14 & 0 & 0 & 1 & 0 \\
\hline Ellesmerian Ivishak AU & 0.9 & Gas & & & & & 0 & 319 & 1,237 & 416 & 0 & 4 & 15 & 5 \\
\hline Ellesmerian Echooka & & Oil & 0 & 0 & 0 & 7 & 0 & 0 & 0 & 5 & 0 & 0 & 0 & 0 \\
\hline North AU & 0.2 & Gas & & & & & 0 & 0 & 0 & 7 & 0 & 0 & 0 & 0 \\
\hline Ellesmerian Echooka & & Oil & 0 & 0 & 0 & 0 & 0 & 0 & 0 & 0 & 0 & 0 & 0 & 0 \\
\hline South AU & 0.48 & Gas & & & & & 0 & 0 & 3,211 & 505 & 0 & 0 & 58 & 14 \\
\hline Ellesmerian Lisburne & 0.54 & Oil & 0 & 0 & 60 & 8 & 0 & 0 & 44 & 6 & 0 & 0 & 1 & 0 \\
\hline North AU & 0.54 & Gas & & & & & 0 & 0 & 938 & 146 & 0 & 0 & 12 & 2 \\
\hline Ellesmerian Lisburne & & Oil & 0 & 0 & 0 & 0 & 0 & 0 & 0 & 0 & 0 & 0 & 0 & 0 \\
\hline South AU & 0.54 & Gas & & & & & 0 & 0 & 2,732 & 646 & 0 & 0 & 81 & 19 \\
\hline Ellesmerian Endicott & 054 & Oil & 0 & 0 & 0 & 3 & 0 & 0 & 0 & 2 & 0 & 0 & 0 & 0 \\
\hline North AU & 0.54 & Gas & & & & & 0 & 0 & 0 & 1 & 0 & 0 & 0 & 0 \\
\hline Ellesmerian Endicott & & Oil & 0 & 0 & 0 & 0 & 0 & 0 & 0 & 0 & 0 & 0 & 0 & 0 \\
\hline South AU & 0.6 & Gas & & & & & 0 & 0 & 3,156 & 522 & 0 & 0 & 41 & 7 \\
\hline & 081 & Oil & 0 & 0 & 0 & 0 & 0 & 0 & 0 & 0 & 0 & 0 & 0 & 0 \\
\hline Ellesmerian Structural AU & 0.81 & Gas & & & & & 0 & 1,613 & 5,675 & 1,990 & 0 & 63 & 226 & 78 \\
\hline & & Oil & 0 & 0 & 43 & 6 & 0 & 0 & 29 & 4 & 0 & 0 & 1 & 0 \\
\hline Thrust Belt AU & 0.72 & Gas & & & & & 0 & 1,327 & 4,240 & 1,521 & 0 & 42 & 140 & 49 \\
\hline Subtotals & & & 0 & 26 & 322 & 86 & 1,946 & 11,335 & 40,429 & 14,732 & 19 & 189 & 768 & 263 \\
\hline $\begin{array}{l}\text { Total undiscovered } \\
\text { conventional resources }\end{array}$ & & & 1,754 & 6,986 & 21,859 & 8,813 & 5,507 & 28,200 & 112,932 & 39,277 & 50 & 341 & 1,439 & 489 \\
\hline
\end{tabular}

\section{Nanushuk-Torok Assessment Team}

David W. Houseknecht, Richard O. Lease, Christopher J. Schenk, Tracey J. Mercier, William A. Rouse, Palma J. Jarboe, Katherine J. Whidden, Christopher P. Garrity, Kristen A. Lewis, Samuel J. Heller, William H. Craddock, Timothy R. Klett, Phuong A. Le, Rebecca A. Smith, Marilyn E. Tennyson, Stephanie B. Gaswirth, Cheryl A. Woodall, Michael E. Brownfield, Heidi M. Leathers-Miller, and Thomas M. Finn

\section{For More Information}

Assessment results are also available at the USGS Energy Resources Program website at https://energy.usgs.gov. 